\title{
The Yutong Bus: Representations of a New Ghanaian Political Metaphor
}

\author{
Eric Opoku Mensah \\ Dept. of Communication Studies, University of Cape Coast, Cape Coast, Ghana \\ Email: eripokuuk@yahoo.co.uk
}

\begin{abstract}
Over last decade, the Ghanaian political discourse has been characterized by insults. This has been of major concern to media commentators, civil society, and other stakeholders in governance in Ghana. One fundamental key in Ghana's political discourse has been the use of metaphor. Using Lakoff and Johnson's (1980) theory of metaphor, the study examines a bus metaphor in recent Ghanaian political speeches. The analysis of the metaphor reveals that the use of metaphors can minimize direct vilification in Ghanaian political communication. The analysis also demonstrates that features of conceptual sources can be manipulated by politicians to achieve positive rhetorical ends. Furthermore, the study supports the fact that positive or negative associations of source domain over a period of time can become a natural part of any given source domain The study has implication(s) for the relationship between political language and human cognition.
\end{abstract}

Index Terms - metaphor, politics, Ghana, source domain, target domain and radio

\section{INTRODUCTION}

The use of metaphors in Ghanaian political discourse is currently gaining some level of prominence. Notable among them are the "tenant and the landlord metaphor" of the former president of Ghana, Flt. Lt. Jerry John Rawlings, during the June $4^{\text {th }}$ celebration, 2011 (TV3, 2011). There is also the Football Coach metaphor which was captured on the political morning show discussion of Adom FM $^{1}$ (Adom FM, 2011). This has continued for a while. Nana Konadu Agyemang Rawlings $^{2}$ (Modern Ghana, 2011) launched her campaign as a presidential candidate of the ruling government party, The National Democratic Congress (NDC). She contested for the presidential candidacy of the ruling party, against the sitting president, Professor John Evans Atta-Mills, for the flag bearer in the 2012 general elections in 2012. During the launching of her campaign, the campaign Chairman, Teye Nyaunu, in his address referred to the sitting president as a driver of a Yutong bus ${ }^{3}$ who was not driving the bus well and needed to give way to another driver since there is the danger of the bus veering off the road. On the following day, $5^{\text {th }}$ of May, 2011, the sitting president after picking his nomination forms also organized a mini political rally which was well attended by party supporters and sympathizers. At this rally, the sitting vice president, John Mahama ${ }^{4}$, took time to rebut the reference of the president as "a bad driver" by using the same metaphor of "the driver" and "the bus" to defend the president. After these two important programmes, what has followed has been a huge political discussion of the "Yutong bus driver metaphor" by media analysts and political commentators in Ghana. This paper therefore attempts to examine the Yutong bus as a positive rhetorical metaphor in the context of heated political dialogue within the NDC and Ghana as a whole.

\section{THEORETICAL BACKGROUND}

This study is based on the cognitive approach pioneered by Lakoff and Johnson (1980) (see also Lakoff 1987, 1993; Lakoff and Turner, 1989) which claims that our ordinary conceptual system, in terms of which we think and act, is fundamentally metaphorical in nature. According to Lakoff, metaphor fundamentally concerns itself with both language and thought, especially, the patterning of everyday metaphorical expressions in language. This, for example, can be seen in LOVE IS A JOURNEY where we can have "we have to part ways", "we have come to the end of the world", "we are at a crossroads"; these are some of the ways human beings conceived the world.

The conceptual metaphor theory looks at two domains in metaphorical mapping that is, the source and the target (Lakoff \& Johnson, 1980). The conceptual mapping between the two domains is unidirectional as against blend theory (Grady et al, 1999) which claims bi-directionality of the metaphorical mapping. There is clear distinction between conceptual metaphorical expressions and linguistic metaphorical expressions (Semino, 2002) which are referred to as conventional and novel metaphors (Grady et al, 1999). It is important to note that Cognitive Scientists (Semino, 2002) have revealed two important aspects of metaphor which had previously not been given any serious prominence: that metaphor usage dominates all forms of discourse; secondly, metaphor is both a linguistic and a conceptual tool. Many arguments have been 
made against conceptual metaphor theory's inability to fully account for novel metaphors (Grady et al, 1999). However, conceptual metaphor theory can account greatly for conventional metaphor which is the focus of this present study.

\section{DATA AND Methodology}

The main data on which this study is based is the recordings of proceedings of the campaign launching of Mrs. Rawlings and the mini rally programme which took place after president Mills picked his nomination forms for the NDC's flag bearer for the 2012 general elections. These two programmes were covered live by Joy $\mathrm{FM}^{5}$ between the $4^{\text {th }}$ and $5^{\text {th }}$ of May 2011. In addition, secondary data were collected through prime time news and political talk show programs on Joy FM and Peace $\mathrm{FM}^{6}$. This was done between the periods of the campaign launchings of the two major political parties, the National Democratic Congress (NDC) and the New Patriotic Party (NPP). The Joy FM and Peace FM were chosen as a source of the data because they both covered the two launchings live on their air waves. Secondly, they broadcast their major programmes through their affiliate FM stations all over the country. This situation provides a unique opportunity for Ghanaian citizens both home and abroad to contribute to political discussions and news either through call- ins or by the sending of SMS messages. The recordings were transcribed and analyzed in detail for metaphorical expressions which constitute the "core" corpus of my study. This core corpus is what I refer to when I talk about "the data" in the rest of this paper. I intend to delve deep into the Yutong bus metaphor in the two speeches to reveal its metaphorical implications within the political discourse in Ghana. All those expressions that can be analyzed in terms of a mapping between two separate domains (Steen, 1999) were selected as part of the metaphorical expressions.

\section{A. Do Metaphors Go by Any System of Interpretation?}

We take a look at the literature on metaphor to put the study into perspective. We examine works on metaphor interpretations and metaphorical mappings.

The interpretation of metaphors is very important in every communication activity. Since politics thrives on communication, it is imperative for politicians to communicate clearly to the populace in order for their message to be understood. In doing, so metaphor becomes one of the crucial tools available to politicians as they make an effort to persuade their audience (Opoku Mensah, 2011). Every given message has an audience. Since an audience has the responsibility to decode the content of a message, it is essential for them to be able to understand figurative language such as metaphors in a given message. The question is, is metaphor interpretation rule governed or not? While many scholars (Margalit, 1972) hold the view that metaphors should be rule governed, Cohen (1975) argues against this assertion:

Given a sentence that is known to be a metaphor, along with the literal meaning of the sentence and components, I think there is no canonical way of arriving at the metaphorical meaning. The metaphorical meaning is somehow constructed out of literal meaning, but not according to any function. Irony, for example, typically incorporates a function that leads from a given meaning to its reverse or opposite. It is not like this metaphor. Whatever it is that a metaphor means, it is not in general true that this meaning can be calculated functionally from the literal meaning of the metaphorical sentence..., although it arises from the literal meaning, it somehow seems to do so spontaneously, and not according to any recognised rule (p. 670).

In a sense Cohen's position demonstrates that there is no rule that governs the interpretation of metaphor. In other words, there is no functional rule that gives us the metaphorical interpretation of a sentence from its literal interpretation, even though the metaphorical interpretation "arises from" the literal one. This indicates that understanding metaphors may not need any technical mind set and therefore is open to the non-technical audience. Cohen concludes that metaphorical interpretation apparently arises from a literal one by virtue of a 'creative mental act'. Davidson (1978) supports this view and concludes that understanding metaphors is a creative endeavor which is little guided by rules.

By contrast, L. Jonathan Cohen and Avishai Margalit (1972) have reasoned as follows.

What is essential to recognise is that the novelty of a metaphor in speech no more constitutes it an innovation in the language than the fact that a sentence has never been uttered before constitutes its utterance a product of syntactic change (471).

In fact, metaphorical ideas could come up spontaneously, and not arbitrarily. The arbitrariness in interpreting metaphors within a given context is further elucidated by Binkley (1974) when he says:

Although the boundaries are not sharp, we all know pretty much what it means to call a person a fox and how one would go about determining whether that assertion is true or false. The claim is no more vague and ill-define, no less connected with definite criteria, than "Richard is a good husband" or "Richard is a scoundrel". What indeterminateness there is in the claim is not something peculiar or endemic to metaphor (p. 174).

Truly, if we say that the interpretation of metaphors is arbitrary then an argument can arise when different people within a single context provide different meanings of that metaphorical utterance which can result in disputes. For Beardsley (1962), disputes about metaphorical interpretations are in principle resolvable. In effect, though metaphorical interpretation is not rule- governed, it may not necessarily lead to confusion in its interpretations. 
Furthermore, Searle (1978, p. 207) argues that “...in general the notion of the literal meaning of a sentence only has application relative to a set of contextual or background assumptions...". Therefore context is very crucial in the interpretation of the Yutong bus and all other metaphors, without which communication cannot be complete in its true sense. This position is supported a step further by Bergmann (1979) who claims that it is only the ideal context that can provide a suitable condition for the interpretation of a metaphor. He indicates:

...not all contexts are ideal contexts in my sense. Perhaps there are very few ideal contexts in actual communicative situations. It is this fact, above all, that gives metaphor its special flavor. For without an ideal context, there are no strict rules for interpretation of metaphors. When we attach specific interpretations to metaphorical expressions, we do something like filling out the ideal context. That is, if in some circumstance there are no special indicators for preferring one way of interpreting a metaphorical expression over a number of others, we may still make a decision as to how the interpretation should be carried out...or we may choose to give the expression a programmatic interpretation saying that no indicative claim is being made but a lot is suggested (p. 228).

These arguments are very important to the present study. So far, it seems the case that in one's attempt to find the metaphorical truths of the Yutong bus metaphor one cannot ignore context which is at the centre for the understanding and interpretation of the metaphor in question.

\section{B. What is the Nature of Metaphorical Mapping?}

Understanding the nature of metaphorical mapping has been the underlying factor in landmark research in metaphorical studies. The revolution of Black's (1962) "implicative complex" cannot be underestimated. Black posits that the two domains clearly interact with each other. On the other hand, Lakoff and Johnson (1980) argue for a uni-directional position between the source and target domains. According to Lakoff and Johnson (1980), conceptual metaphor is when we understand one thing (source) in terms of another (target). For them, uni-directional mapping is from source domain to target domain and not the other way round. Kovecses (2002) states that:

When we talk and think about life in terms of journeys, about arguments in terms of war, about love in terms of journeys, about theories in terms of plants...

To Kovecses, this is what is meant by conceptual metaphor. Beyond uni-directionality is bi- directionality.

Arguments underlying metaphorical mappings and domains have engaged the attention of major metaphor theorists. Semino (2002) in her work explains the metaphors which were used to describe the euro in both Italian and British newspapers. Focusing on the euro as a target domain, Semino tries to prove the similarities in the conceptual metaphorical systems which underlie both British and Italian newspapers. Though there are similarities, the work reveals that some metaphors from both the British and Italians newspapers reveal the different positions of the two countries regarding the adoption of the euro as a single currency. In conclusion, the work shows that the most frequent metaphorical patterns in each language draw from source domains which are not specific to the euro target domain but are applied to a wide range of other target domains.

\section{The Nature of Metaphorical Mapping}

Metaphorical mapping has been a major concern to critics since it gives direction to conceptualization of the metaphorical process. So what is the nature of metaphorical mapping? Several works over the period (Richards, 1936; Lakoff and Johnson, 1980; Hausman, 1986; Kelly and Keil, 1986; Black, 1979) have supported the two domain structure of the metaphor. The two domains have been given several references. But the terms used by Lakoff and Johnson (1980) is what will be used in this study. They talk about source and target. The source is the domain from which concepts originate and the target is the domain to which concepts are mapped. The metaphorical mapping is between the source and target concepts and the mapping is uni-directional (Lakoff and Johnson, 1980) that is, from source to target but not vice versa. The uni- directional position of Lakoff and Johnson (1980) has been opposed by other leading exponents of the subject (Black, 1979; Croft and Cruse, 2004; Fauconnier and Turner, 1994). The source domain is conceptualized as being more closely related to physical experience (Grady, 1997). It is important to indicate that the metaphorical mapping can be one to - one, one -to-many, many -to one and many to many (2004). This study will focus on the one-to-one (Lakoff and Johnson, 1980) and one-to-many domain mappings (Kovecses, 2002; Morgan and Bales, 2002).

In the one-to-one domain relationship a single source domain is mapped unto a single target domain. On the other hand, the one-to-many domain relationship, a single source domain is mapped unto many target domains.

\section{The History of Yutong Bus in Ghana}

As part of the NDC government's effort in augmenting inter city transportation in Ghana, the government in collaboration with Stanbic Bank imported 490 Yutong buses for the use of The Ghana Private Road and Transport Union (GPRTU). The buses were formally launched on $9^{\text {th }}$ August 2010 by the Vice President, John Mahama, at La, in Accra (www.ghanaweb.com). According to the story, this was in fulfilling the government's effort "to make the transportation sector viable, smooth and devoid of road accidents" (www.ghanaweb.com). The Yutong bus at this moment in Ghana's 
transportation, was gradually gaining patronage and popularity until 11th October 2011, an armed robbery attack on a Yutong bus which was bound for Bolgatanga in the Upper West region of Ghana. The story alleges that the armed robbers ordered a mass rape among male and female passengers. The story further quotes that:

Amina Mohammed, 24, a mother of three, reported how armed robbers attacked their Bolgatanga bound Yutong bus and in the process the robbers ordered a mass rape of female occupants; male passengers were forced to have sex with their female counterparts.

Perhaps the gut-churning aspect of the tale for most Ghanaians, was the part that the robbers allegedly forced a father who was on the bus to sleep with his I4-year-old daughter, deflowering her in the process (www.ghanamma.com/2011/02/25).

This armed robbery incident on the Yutong bus attracted a lot of media and social debates all over the country. Not long after this supposedly bizarre incident, www.modernghana.com reports Daily Guide which carries a story entitled 'Amina Bus' in another Accident. The story reads:

A Yutong bus and an Opel Vectra saloon car were last Saturday involved in an accident at Bechem, Brong Ahafo Region, with over 40 passengers sustaining various degrees of injury.

In yet, another story, www.ghanaweb.com on $11^{\text {th }}$ January 2011 carries a report by Peaceonline of an accident involving two Yutong buses entitled: Two Yutong Buses Crash, Killing 20. The story reads:

Information reaching Peacefmonline.com indicates that two Yutong buses crashed in a head-on collision this dawn leading to the tragic death of about 20 people.

At this moment, the reports of gruesome activities involving the Yutong buses would have naturally created negative attachment with any image of the Yutong bus, especially at a time when no positive story involving the bus was captured to ameliorate the already mounting negative associations which have now been deeply associated with the bus. It is in the light of these negative Ghanaian media reports involving the Yutong bus that the 'Yutong bus metaphor' becomes of a major rhetoric concern within recent political developments largely within the ruling NDC Party and the entire Ghanaian political discourse

\section{E. The Driver and the Yutong Bus}

The Yutong bus metaphor presents a group of people who are travelling on a Yutong bus. Along the journey some passengers realize the driver is not driving too well and that there is the high possibility of the bus veering of the road into a ditch. According to Teye Nyaunu, while some of the passengers on the bus are sleeping, others are wide awake but are afraid to warn the driver of his reckless driving. The story concludes that the bus driver should be changed in order to save the lives of the passengers on board the vehicle. This metaphor presents several scenarios for discussion. I will present Nyaunu's metaphor in a simple tabular form.

TABLE 1:

TEYE NYAUNU'S METAPHOR

\begin{tabular}{|l|l|}
\hline Source & Target \\
\hline Yutong bus & NDC party/government \\
\hline Driver & the president \\
\hline Passengers & party members \\
\hline Bad driving & poor leadership \\
\hline Journey & four-year term \\
\hline Angry passengers & people critical of government policies \\
\hline
\end{tabular}

The above table (1), indicates a direct one-to- one mapping from source to target. The Yutong bus maps unto the domain of government and the bad driver maps unto the president. The story indicates that the "bus is good but it is the driver that is bad". We may be tempted not to believe that statement. This position may arise because of the numerous accidents recorded by the Yutong bus in Ghana, not forgetting the infamous rape incident. Therefore the negative conceptual frames which have quickly become associated with the Yutong bus naturally rubs unto the president, that is, if there is a direct mapping between the driver and the president. This position is further reinforced by the image of the bad driver (the president) which constantly gets the bus involved in numerous road accidents. At this point, the picture of a bad leader who is mismanaging government business is brought to the fore.

Also, we can take a look at the passengers (NDC party members) on board the bus some of whom are sleeping while others are awake. Sleeping passengers onboard the bus maps directly unto "politically unconcerned party members" while passengers who are awake on the bus maps unto "politically conscious party members." The journey represents the fouryear term and the bad driving corresponds to poor governance style. The entire mapping is uni-directional. This physical experience of a journey on a bus enables us to understand the abstraction of the president's governance style and how citizens respond to it (Grady, 1997). The simplicity of the mapping may perhaps, allow readers to appreciate the message carried by the metaphor (Cohen, 1975). 
Secondly, because of the context of the metaphorical utterance which was given enough space on radio discussion, listeners without doubt, understood the metaphor without having to question for example who the bus driver was (Searle, 1978). This is evidenced by the numerous text messages which were read on the two radio networks which provided coverage of the campaign program on their air waves. This reinforces the relevance of context in audience understanding of any given metaphorical utterance.

\section{F. Passengers should Encourage the Driver}

A day after the first speech of the Yutong bus was made, the Vice President of Ghana at a ceremony rebuts the message of the Yutong bus. Interestingly, he does this using the same metaphor as a tool for his rhetorical argument. This can be roughly reduced to a mapping table like this:

TABLE 2:

JOHN MAHAMA'S METAPHOR

\begin{tabular}{|l|l|}
\hline Source & Target \\
\hline Driver & president \\
\hline Bus & the nation/ NDC party \\
\hline Passengers & Ghanaian citizens/ NDC party members \\
\hline Calm-tempered passengers & citizens/party members supportive of government policies \\
\hline Journey & national governance life \\
\hline Car's engine capacity & the capacity of the nation's economy \\
\hline
\end{tabular}

Table 2 maintains some conceptual mappings in Table 1 but present some differences. The conceptual domain driver still maps unto the target domain which is the president. The Yutong bus roughly maps unto the target domains the nation and NDC party members. The passengers maps unto citizens and NDC part members. The source domains bus and passengers have one - to - two mappings.

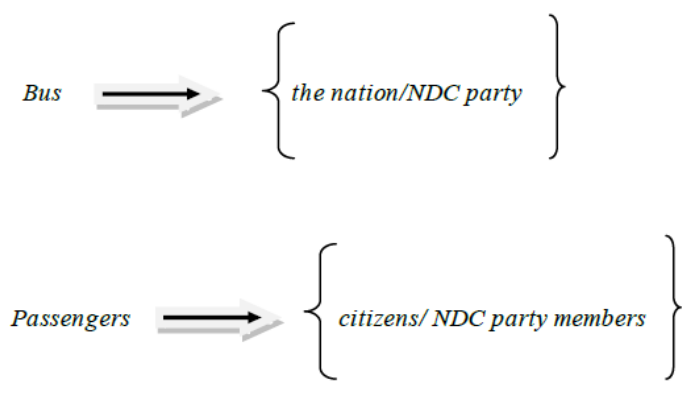

The one-to-two mapping of the two source domains (bus and passengers) has implication for the understanding of the speaker's message. In the original metaphor, the concepts bus and passengers mapped unto single target domains. The additional target domains by the speaker demonstrate rhetorically that the mandate of the president is beyond the control of the NDC party since it is a constitutional mandate of the people of Ghanaian people irrespective of their political inclination. As a result, the NDC party and its members cannot take that sole decision to change him as the president of the republic of Ghana.

This is supported by the speaker's introductory remarks:

If Ghana were a bus... we have had many drivers of that bus in the past.

In addition, the speaker consciously violates the features of the conceptual source domain which is the passengers. This brings out two main issues. First, it is not the normal situation for passengers on a travelling bus to be prompting the driver about potholes and stationary vehicles ahead.

... what we have done in the past is to watch out for potholes so that the driver won't fall in, what we have done in the past is to watch out for stationary vehicles so that the bus will not crash into a stationary vehicle. What we have done in the past is that even when the driver is sleeping we offer him coffee so that he will stay awake.

In the above statement, it however seems that when a driver is not driving well, passengers, for the fear of a fatal accident, will criticize the driver and possibly think about the possibility of drawing the attention of authorities to relieve the driver of his (in this situation the president of Ghana) duties. This results in a change of the features of the source domain (passengers), so that instead of party members being critical of the driver's work, they would rather want to encourage him. This rhetorical maneuvering by the speaker presents the target domains (citizens/ party members) naturally incompatible with the features of the source domain, passengers.

Secondly, since the president (driver) can only be legitimately removed from office government at the end of its fouryear term (journey), the only way to handle the situation is for citizens (passengers) to tolerate the president (driver) 
through the rest of his four year-term (journey). In other words, an incompetent driver of a bus cannot be changed in the middle of the journey when there is no alternative driver on the bus. It can possibly happen when the bus reaches its final destination which will be at the end of the four - year term. This argument provides a justification for supporting the sitting president (driver). That is, citizens (passengers) have no choice as long as the journey of the four-year term has not come to an end. Therefore, it will be only appropriate to support the president (driver) by supporting his policies to work (providing coffee and so on) in order for him to end his four-year term (journey) successfully (safely).

\section{G. Extensions of the Yutong Bus Metaphor}

Following the two main speeches of Teye Nyaunu, the campaign manager, and John Mahama, the vice president, which carried the Yutong bus metaphor, subsequent radio and television programmes revealed different references of the same metaphors as other social and political issues were brought up for discussion. A few of such relevant examples will be discussed below.

The sitting president of the Ghana Football Association (GFA) was nominated by the government to contest for a continental position on the Federation for African Football (CAF). Shortly after this was done, the government came out to endorse a new person for the same position and decided to rescind its initial proposition concerning the first nominee. A panelist on News File ${ }^{7}$ (14 ${ }^{\text {th }}$ May 2011), in response to the equivocation of government on the above issue indicated that:

if you are a driver of the Yutong bus and you signal left but turn right, it may lead to an accident on the road.

The speaker in the above metaphor continues the metaphor of "the bad driver". Here he invokes the image of the inexperienced driver whose signals other road users in a particular direction but does otherwise thereby causing commotion. This is a sign of incompetence as a driver and a mapping of this concept will refer to a bad government. This demonstrates that people can create novel metaphors and it can be done spontaneously in the course of conversation. It may not necessarily be the case that the speaker of the above utterance had well calculated the metaphoreven before the topic was brought up for discussion.

On a popular political talk show programme $\operatorname{Krokokoo}^{8}$ (Kokrokoo, May 20 2011), an sms message sent as a contribution to the programme highlights the competence of the sitting president by saying:

When Rawlings was driving the OSA bus, Atta Mills was the 'mate'. Now Atta Mills is driving the Yutong bus which is automatic, therefore he can drive the vehicle better.

In this statement, the writer employs the bus metaphor by tracing the experience of the driver as a mate ${ }^{9}$ (driver's assistant) which maps onto the office of the vice president. The "driver" maps unto the President. Since the sitting president was once a vice president, he has gathered enough experience to manage his administration as a driver (president). Interestingly, according to the content of the message, the sitting president was an assistant on an OSA bus ${ }^{10}$ but he is now a driver on a Yutong bus which has an automatic transmission. The comparison of the manual OSA bus and the automatic transmission Yutong bus is striking. The message suggests that the automatic transmission is effective than a manual transmission system in vehicles. It should be noted that the new Yutong bus, perhaps, may have an improved technology and efficiency than the old OSA buses. The message therefore implies that the sitting president with his current administration machinery (automatic Yutong bus) may have become more competent in view of his long period of apprenticeship (mate). The extension of the Yutong bus metaphor in this sense seems novel.

In another development, a radio programme (Adom, 2011) discusses how some NDC party members have become disgruntled as a result of not getting political appointments in the current government. An NDC panelist on the program indicates that:

...the Yutong bus is en route to Cape Coast but it will make several stops on the way, some will get on board and off boad at different stops. So until the bus gets to its final destination, part members should not be worried.

This statement also brings out an entirely different dimension of the bus metaphor. It can be mapped graphically as this:

\begin{tabular}{|l|l|}
\begin{tabular}{|l|l|}
\hline Source & Target \\
\hline Driver & president \\
\hline Bus & the government \\
\hline Passengers & government appointees \\
\hline Journey & four-year term \\
\hline
\end{tabular}
\end{tabular}

The speaker exploits the way by which the public transport system works for the purpose of his sending his message across. Unlike the previous mapping of passengers unto NDC party members/ Ghanaian citizens, passengers now maps unto the target domain government appointees. Therefore, just like passengers get on and off the bus along the bus' route, the speaker encourages the NDC party members who have yet not had any political appointed that they will get their opportunity at the right time. 


\section{CONCLUSION}

The Yutong bus metaphor is a novelty in recent Ghanaian political discourse. Though Ghana's democracy is gradually gaining roots, it has been characterized by serious vituperations in the media. This negative picture of Ghanaian political discourse has been a major source of worry to all and sundry. This has attracted criticisms from politicians and civil society including personalities like the sitting president of Ghana, John Evans Atta Mills (2010), the clergy (Otabil, 2011) and the Asante King, Otumfuo Osei Tutu (2011).

With this rising concern, the recent use of the Yutong bus as a metaphor in engaging a serious political subject within and outside the ruling NDC party is a positive sign in the body politics of Ghana. In other words, the bus metaphor clearly brings to the fore the unique roles metaphor can play in any given rhetorical discourse (Opoku Mensah, 2011). Indeed, the use of metaphors in political discourse will enhance the beauty and understanding of political messages. In effect, this paper has shown that politicians in Ghana and elsewhere can employ metaphor to discuss serious political issues without resorting to insults of their political opponents. This is not to posit that metaphor cannot be used for insults but I prescribe it instead of engaging in direct vituperations. Secondly, the discussions have shown that associations of conceptual sources can be manipulated by persuasive speakers to achieve rhetorical purposes as demonstrated in this paper. Finally, negative associations which become a part of a conceptual source over time become naturally transferred unto features of the target domain. All these can be explored for the purposes of proper communication.

Notes:

1. Adom FM - A popular Akan radio station based in Accra, Ghana

2. Nana Konadu Agyemang Rawlings - the first First Lady of the Fourth Republic of Ghana

3. Yutong bus - it a new bus which was imported by the NDC government with collaboration with Stanbic Bank to enhance Ghana's intra-city transportation.

4. John Mahama - The sitting Vice president of the Republic of Ghana

5. Joy FM - a popular English language radio station in Accra, Ghana

6. Peace FM - A popular Akan radio station based in Accra, Ghana

7. News File - a popular political talk show programme on Joy FM

8. Krokokoo - the morning talk show programme on Peace FM

9. Mate - the term used for a bus assistant normally on a public transport in Ghana

10. OSA bus - Public bus companies have operated in Ghana since the Ominibus Service Authority (OSA) started its operations in 1927. The OSA contributed a lot to the Ghanaian society in terms of public transport. However, OSA's assets were divested in 1995.

\section{ACKNOWLEDGEMENT}

I want to show appreciation to Dr. J.B.A. of the Department of English, University of Cape Coast, for his critical comments and suggestions. Not forgetting the noise and cries of Michelle and Michael. Abi, you are always remembered in difficult times of writing.

\section{REFERENCES}

[1] Bergmann, M. (1979). "Metaphor and formal semantic theory". Poetics. ( $8^{\text {th }}$ ed.), North Holland Publishing Company.

[2] Black, M. (1962). Models and Metaphor. Ithaca. NY: Cornell University Press.

[3] Black, M. (1979). 'More on metaphor'. In A. Ortony (ed.) Metaphor and Thought. Cambridge: CUP. 1-18.

[4] Binkley, T. (1974). On the Truth and Probity of Metaphor. In Journal of Aesthetics and Art Criticism. 33, 171-180.

[5] Cohen, T. (1975). "Figurative speech and figurative acts". Journal of Philosophy. 72, $44-47$.

[6] Croft, W. \& Cruse, D.A. (2004). Cognitive Linguistics. Cambridge: Cambridge University Press.

[7] Davidson, D. (1978). "What metaphor mean". Critical Inquiry, 5, 25-27.

[8] Dwaso Nsem, Adom FM, 5th June 2011, $0900 \mathrm{hrs}$

[9] Fauconnier, G. \& Turner, M. (1994). Conceptual Projection and Middle spaces. University of California, San Diego Department of Cognitive Science Technical Report 9401. [Compressed (Unix) postscript version: 9401.ps.Z].

[10] Grady, J.,T. Oakley \& S. Coulson. (1999). Blending and metaphor. In Metaphor in Cognitive Linguistics, G. Steen\& R. Gibbs (eds.). Philadelphia: John Benjamins

[11] Grady, J. (1997). Foundations of Meaning: Primary Metaphors and Primary Scenes. Unpublished Ph.D. dissertation, University of California, Berkeley.

[12] Hausman, C. (1989). Metaphor and Art. New York: Cambridge University Press.

[13] Johnson, Mark. (1987). The Body in the Mind: The Bodily Basis of Meaning, Imagination and Reason. Chicago: The University of Chicago Press.

[14] Kovecses, Z. (2002). Metaphor. A Practical Guide. Oxford: Oxford University Press. 
[15] Lakoff, G. (1987). Women, Fire, and Dangerous Things: What Categories Reveal about the Mind. Chicago: The University of Chicago Press.

[16] Lakoff, G. (1993). The contemporary theory of metaphor. In Ortony, A. (ed.), Metaphor and thought. Cambridge: Cambridge University Press, 202-251.

[17] Lakoff, G. \& Johnson, M. (1980). Metaphors we live by. The Univ. of Chicago Press, Chicago.

[18] Lakoff \& Turner, M. (1989). More than cool reasoning: A field guide to poetic metaphor. Chicago: The University of Chicago Press.

[19] Kelly, M. \& Keil, F. (1987). 'Metaphor comprehension and knowledge of semantic domains.' In Metaphor and Symbolic Acitivity. 2, 33-52.

[20] Kovecses, Z. (2002). Metaphor: A Practical Guide. Oxford: OUP

[21] Morgan, P \& Bales, S. (2002). 'Competition, Cooperation and, Connection: How these Metaphors Affect Child's Advocacy'. Frameworks Institute Kids Count E-Zine. Issue no. 11, 1-2

[22] News at Seven TV3, $6^{\text {th }}$ June $2011,1800 \mathrm{hrs}$

[23] Opoku Mensah, E. (2011). The Metaphor a rhetorical tool in some selected political speeches of Martin Luther King, Jr. and Kwame Nkrumah. Language in India, Vol. 11, pp. 155 - 172.

[24] Richards, I. A. (1936). The Philosophy of rhetoric. New York: Open University Press.

[25] Semino, E. (2002). A sturdy baby or a derailing train? Metaphorical representations of the euro in British and Italian newspapers. in Text , 22, 1, 107-39, 2002.

[26] Daily Guide. (2011). 'Amina bus' in another accident'. http://www.modernghana.com/news/316237/1/amina-bus-in-anotheraccident.html. Accessed on 11/08/2011

[27] Daily Guide. (2011). 'Nana Konadu Launches Campaign...Hits Road Running'. http://www.dailyguideghana.com/?p=11203. Accessed on 12/08/2011.

[28] Ghana Broadcasting Corporation. (2010). Asantehene decries politics of insults especially on Presidency. Ghana Broadcasting Corporation, Ghana. http://www.gbcghana.com/index.php?id =1.334000.1.450233. Accessed on 11/08/2011

[29] GhanaWeb. (2010). 'Veep Launches $400 \quad$ Yutong http://www.ghanaweb.com/GhanaHomePage/NewsArchive/artikel.php?ID=187904. Accessed on 11/08/2011

[30] GhanaWeb. (2010). 'Insults tainting Ghana's politics - Prez Mills' General News, Ghana. http://www.ghanaweb.com/, GhanaHomePage/NewsArchive/artikel.php?ID=196197. Accessed on 11/08/2011

[31] JoyOnline. (2011). 'Mensah Otabil decries politics of insults; calls for revolution'. Joy FM News, Ghana. http://news.myjoyonline.com/news/201103/63310.asp. Accessed on 11/08/2011

[32] JoyOnline. (2011). 'NDC is veering off the road; let's change the driver'. Joy FM News, Ghana. http://news.myjoyonline.com/naudio/201105/126.asp. Accessed on 12/08/2011

[33] Kings Radio. (2011). 'Amina bus rape: Ken Agyapong Implicated' http://www.kingsradiogh.com/news/detail.php?id=95\&pag=8. Accessed on 11/08/2011

[34] Modern Ghana. (2011). 'Nana Konadu Launches Campaign'. http://www.modernghana.com/news/327595/1/. Accessed on $11 / 08 / 2011$

[35] Peacefmonline. http://www.ghanaweb.com/GhanaHomePage/NewsArchive/artikel.php?ID=201045. Accessed on 11/08/2011

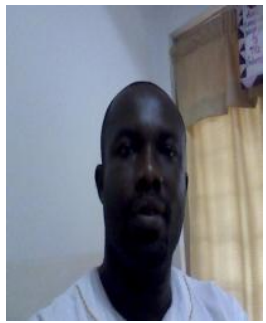

Eric Opoku Mensah was born in Accra, the capital city of Ghana in 1978. He read for his BA (Hons) Arts degree (English Language) at the University of Cape Coast in Ghana which he completed in 2003. He further pursued a Master of Philosophy Degree in English Language at the same University which he successfully completed in 2008. He is currently a PhD candidate at the Centre for Rhetoric Studies, University of Cape Town, South Africa. His major area of research is in metaphor and rhetorical discourse with special interest in political communication.

He has presented papers and actively participated in both international and local workshops and conferences including recently the Rhetoric in Society III Conference held in January 2011 in Antwerp, Belgium. He is a lecturer at the Department of Communication Studies, University of Cape Coast, Ghana. His last publication is entitled "The Metaphor: A Rhetorical Tool in Selected Speeches of Martin Luther King, Jr. and Kwame Nkrumah" (Opoku Mensah, E., Language in India, 2011). He is currently working on the rhetoric of personal stories in political speeches and the interface between language and cognition.

Mr. Opoku Mensah, among other things, is a member of the Ghana Association of Language Teachers and also the prestigious Rhetoric in Africa. He is a current contributor to the Communication Skills Manual of the University of Cape Coast. 